\title{
KESETARAAN DALAM PERJANJIAN KERJA DAN AMBIGUITAS PERTIMBANGAN HUKUM MAHKAMAH KONSTITUSI
}

\author{
Kajian Putusan Mahkamah Konstitusi Nomor 13/PUU-XV/2017
}

\section{EQUALITY IN WORK AGREEMENT AND AMBIGUITY IN LEGAL CONSIDERATION OF THE CONSTITUTIONAL COURT}

\author{
An Analysis of Constitutional Court Decision Number 13/PUU-XV/2017
}

\author{
Ayunita Nur Rohanawati \\ Departemen Hukum Administrasi Negara Fakultas Hukum Universitas Islam Indonesia \\ Jl. Taman Siswa No. 158, Yogyakarta 55111 \\ E-mail: ayunita.nur@uii.ac.id \\ Dian Agung Wicaksono \\ Departemen Hukum Tata Negara Fakultas Hukum Universitas Gadjah Mada \\ Jl. Sosio Yustisia No. 1 Bulaksumur, Sleman, Yogyakarta 55281 \\ E-mail: dianagung@ugm.ac.id
}

Naskah diterima: 19 Februari 2018; revisi: 5 November 2018; disetujui: 6 Desember 2018

http://dx.doi.org/10.29123/jy.v11i3.307

\begin{abstract}
ABSTRAK
Putusan Mahkamah Konstitusi Nomor 13/PUU$\mathrm{XV} / 2017$ terkait pembatalan aturan larangan pernikahan antar-karyawan sekantor, dinilai sebagai bentuk jaminan pemenuhan hak asasi manusia, berupa hak membentuk keluarga melalui perkawinan yang sah sebagaimana tertuang dalam Pasal 28B ayat (1) UUD NRI 1945. Pertimbangan hukum putusan tersebut memuat asas kebebasan berkontrak sebagai salah satu syarat sahnya perjanjian dan persepsi ketidaksetaraan dalam perjanjian kerja. Menarik untuk dikaji, bagaimana konstruksi hukum perjanjian kerja, khususnya kesetaraan pihak. Mengingat asas kebebasan berkontrak merupakan salah satu asas dalam perjanjian yang mengindikasikan adanya ketidakcacatan kehendak, maka pertanyaan lebih lanjutnya, apakah betul perjanjian kerja tidak memberikan kesetaraan kepada para pihak sebagaimana
\end{abstract}

yang didalilkan oleh Mahkamah Konstitusi? Apakah konsekuensi yuridis Mahkamah Konstitusi mendudukkan asas kebebasan berkontrak sebagai salah satu syarat sahnya perjanjian, yang mana hal ini bertolak belakang dengan ketentuan dalam Pasal 1320 KUHPerdata? Penelitian ini merupakan penelitian hukum normatif dengan studi kasus mengkaji bahan hukum primer berupa Putusan Mahkamah Konstitusi Nomor 13/PUU-XV/2017. Penelitian ini dilakukan melalui pendekatan peraturan perundang-undangan dan pendekatan konseptual. Data dianalisis secara deskriptif-kualitatif. Hasil penelitian ini setidaknya menunjukkan bahwa dalam putusan tersebut, khususnya pada bagian pertimbangan, Mahkamah Konstitusi memberikan ambiguitas pertimbangan hukum, yang notabene bertentangan dengan pengaturan terkait syarat sah perjanjian. 
Kata kunci: kesetaraan pihak, perjanjian kerja, keabsahan perjanjian, ratio decidendi.

\section{ABSTRACT}

The Constitutional Court Decision Number 13/PUU$X V / 2017$ related to the cancellation of rules regarding the prohibition of co-worker marriage, is considered as a form of guaranteeing the fulfilment of human rights, which is the right to form a family through legal marriage as stated in Article 28B paragraph (1) of the 1945 Constitution. However, the decision contains legal considerations related to the principle of freedom of contract as one of the legal requirements of an agreement, and the perception of inequality in work agreement. It is interesting to examine the legal construction of equality of parties in work agreement as the principle of freedom of contract is one of the principles in the agreement indicating no defects on the parties' will.
Then, the further question is whether it is right that work agreement does not provide equality to the parties as argued by the Constitutional Court. What are the juridical consequences of the Constitutional Court to establish the principle of freedom of contract as one of the legal requirements of an agreement, which is contrary to the provisions of Article 1320 of the Civil Code? This is a normative legal research through case study to examine the Constitutional Court Decision Number 13/PUU-XV/2017. This research uses statutory and conceptual approach based on descriptive-qualitative data analysis. The results of this study at least indicate that in the decision, especially in legal considerations, the Constitutional Court has provided ambiguity in legal considerations, which in fact contradicted the regulations regarding the legal terms of an agreement.

Keywords: equality of parties, work agreement, validity of contract, ratio decidendi.

\section{PENDAHULUAN}

\section{A. Latar Belakang}

Putusan Mahkamah Konstitusi Nomor 13/PUU-XV/2017 perihal pengujian UndangUndang Nomor 13 Tahun 2003 tentang Ketenagakerjaan terhadap UUD NRI 1945, khususnya pada Pasal 153 ayat (1) huruf f yang diuji dengan Pasal 28B ayat (1) UUD NRI 1945 memberikan harapan baru terhadap jaminan pemenuhan hak asasi manusia, khususnya terkait hak untuk menikah dan membentuk keluarga melalui perkawinan yang sah.

Putusan tersebut menyatakan bahwa frasa "kecuali telah diatur dalam perjanjian kerja, peraturan perusahaan, atau perjanjian kerja bersama" pada Pasal 153 ayat (1) huruf fUndangUndang Ketenagakerjaan bertentangan dengan UUD NRI 1945 dan tidak mempunyai kekuatan hukum mengikat. Putusan tersebut meneguhkan pengaturan bahwa pengusaha dilarang melakukan pemutusan hubungan kerja dengan alasan pekerja/ buruh mempunyai pertalian darah dan/atau ikatan perkawinan dengan pekerja/buruh lainnya di dalam satu perusahaan, atau dapat dikatakan bahwa tidak ada lagi aturan mengenai no-spouse employment yang diatur dalam perjanjian kerja.

Konteks praktiknya, sudah menjadi rahasia umum bahwa sebelum adanya Putusan a quo hubungan kerja menjadi penghalang dilaksanakannya perkawinan di antara individu yang bekerja dalam satu perusahaan, sehingga yang harus ditempuh adalah salah satu di antara pasangan tersebut harus mengundurkan diri dari perusahaan tempatnya bekerja. Betul memang konstruksi Pasal 153 ayat (1) huruf f UndangUndang Ketenagakerjaan belum tentu diterapkan secara ketat, karena didapati pula perusahaan yang tidak mempermasalahkan adanya ikatan perkawinan di antara pekerja dalam satu perusahaan. Walaupun demikian, dalam konteks pengujian undang-undang memang tidak 
diharuskan adanya kerugian yang diderita oleh seluruh warga negara Indonesia, melainkan cukup didalilkan adanya kerugian konstitusional yang diderita oleh pemohon pengujian undangundang.

Konstruksi kerugian konstitusional ini terkait erat dengan konsep legal standing atau kedudukan hukum pemohon dalam pengujian undang-undang di Mahkamah Konstitusi. Siahaan (2006: 80) menjelaskan syarat yang harus dipenuhi agar sebuah permohonan memiliki legal standing dalam konsep peradilan di Amerika, yaitu: (a) adanya kerugian yang timbul karena adanya pelanggaran kepentingan pemohon yang dilindungi secara hukum yang memiliki dua sifat, yaitu spesifik (khusus) dan aktual dalam menimbulkan kerugian (bukan potensial); (b) adanya hubungan sebab akibat atau hubungan kausalitas antara kerugian dengan berlakunya satu undang-undang (hal ini terkait pengujian konstitusionalitas undang-undang); dan (c) kemungkinan dengan diberikannya keputusan yang diharapkan, maka kerugian akan dihindarkan atau dipulihkan.

Spesifik dalam konteks hukum positif Indonesia, pada Pasal 51 ayat (1) Undang-Undang Nomor 24 Tahun 2003 tentang Mahkamah Konstitusi disebutkan bahwa konstruksi legal standing terkait dengan kerugian hak dan/atau kewenangan konstitusional harus memenuhi lima syarat, yaitu:

1. Adanya hak dan/atau kewenangan konstitusional pemohon yang diberikan oleh UUD NRI 1945;

2. Hak dan/atau kewenangan konstitusional tersebut oleh pemohon dianggap dirugikan oleh berlakunya undang-undang yang dimohonkan pengujian;
3. Kerugian hak dan/atau kewenangan konstitusional tersebut harus bersifat spesifik (khusus) dan aktual atau setidaktidaknya potensial yang menurut penalaran yang wajar dapat dipastikan akan terjadi;

4. Adanya hubungan sebab-akibat (causal verband) antara kerugian dimaksud dan berlakunya undang-undang yang dimohonkan pengujian; dan

5. Adanya kemungkinan bahwa dengan dikabulkannya permohonan, maka kerugian hak dan/atau kewenangan konstitusional seperti yang didalilkan tidak akan atau tidak lagi terjadi.

Dengan demikian, cukup dengan didalilkannya kerugian oleh para pemohon pada Putusan Nomor 13/PUU-XV/2017 untuk menguji Undang-Undang Ketenagakerjaan terhadap UUD NRI 1945 sudah cukup untuk menjadi dasar kedudukan hukum para pemohon.

Terlepas dari aspek amar Putusan Nomor 13/PUU-XV/2017 yang meneguhkan pengaturan bahwa pengusaha dilarang melakukan pemutusan hubungan kerja dengan alasan pekerja/buruh mempunyai pertalian darah dan/atau ikatan perkawinan dengan pekerja/buruh lainnya di dalam satu perusahaan, terdapat aspek lain dalam Putusan a quo yang menarik untuk dikaji lebih lanjut. Bagian pertimbangan hukum Putusan a quo, khususnya pada pokok permohonan, setidaknya menegaskan dua hal, yaitu:

1. Perkawinan adalah takdir dan tidak dapat menjadi dasar pembatasan hak asasi manusia. Mahkamah Konstitusi menegaskan bahwa:

[...] pertalian darah atau hubungan perkawinan adalah takdir yang 
tidak dapat direncanakan maupun dielakkan.Olehkarenaitu,menjadikan sesuatu yang bersifat takdir sebagai syarat untuk mengesampingkan pemenuhan hak asasi manusia, dalam hal ini hak atas pekerjaan serta hak untuk membentuk keluarga, adalah tidak dapat diterima sebagai alasan yang sah secara konstitusional. Sesuai dengan Pasal 28J ayat (2) UUD NRI 1945 pembatasan terhadap hak asasi manusia hanya dapat dilakukan dengan maksud semata-mata untuk menjamin pengakuan serta penghormatan atas hak dan kebebasan orang lain dan untuk memenuhi tuntutan yang adil sesuai dengan pertimbangan moral, nilai-nilai agama, keamanan, dan ketertiban umum dalam suatu masyarakat demokratis. Pembatasan sebagaimana termuat dalam Pasal 153 ayat (1) huruf $\mathrm{f}$ UndangUndang Nomor 13 Tahun 2003 tidak memenuhi syarat penghormatan atas hak dan kebebasan orang lain karena tidak ada hak atau kebebasan orang lain yang terganggu oleh adanya pertalian darah dan/atau ikatan perkawinan dimaksud. Demikian pula tidak ada norma-norma moral, nilai-nilai agama, keamanan, dan ketertiban umum dalam suatu masyarakat demokratis yang terganggu oleh adanya fakta bahwa pekerja/buruh dalam satu perusahaan memiliki pertalian darah dan/atau ikatan perkawinan [...].

2. Mendudukkan asas kebebasan berkontrak sebagai salah satu syarat sahnya perjanjian dan persepsi ketidakseimbangan pihak dalam perjanjian kerja, sehingga karena sejak awal tidak terdapat keseimbangan, maka asas kebebasan berkontrak dicederai. Hal ini ditegaskan oleh Mahkamah Konstitusi dalam pertimbangan bahwa:
[...] argumentasi yang mendasarkan pada doktrin pacta sunt servanda dengan menghubungkannya dengan Pasal 1338 KUHPerdata yang menyatakan, "semua persetujuan yang dibuat sesuai dengan undang-undang berlaku sebagai undang-undang bagi mereka yang membuatnya. Persetujuan itu tidak dapat ditarik kembali selain dengan kesepakatan kedua belah pihak, atau karena alasan-alasan yang ditentukan oleh undang-undang. Persetujuan harus dilaksanakan dengan iktikad baik," menurut Mahkamah Konstitusi, argumentasi demikian tidak selalu relevan untuk diterapkan tanpa memperhatikan keseimbangan kedudukan para pihak yang membuat persetujuan tersebut ketika persetujuan itu dibuat. Dalam kaitan ini, telah terang kiranya bahwa antara pengusaha dan pekerja/buruh berada dalam posisi yang tidak seimbang. Sebab pekerja/buruh adalah pihak yang berada dalam posisi yang lebih lemah karena sebagai pihak yang membutuhkan pekerjaan. Dengan adanya posisi yang tidak seimbang tersebut, maka dalam hal ini filosofi kebebasan berkontrak yang merupakan salah satu syarat sahnya perjanjian menjadi tidak sepenuhnya terpenuhi $[\ldots]$.

Kedua pertimbangan hukum pada pokok permohonan di atas menarik untuk ditelaah lebih lanjut, namun dalam konteks penelitian ini kajian difokuskan pada pertimbangan hukum pada pokok permohonan kedua, yaitu mendudukkan asas kebebasan berkontrak sebagai salah satu syarat sahnya perjanjian dan persepsi ketidakseimbangan pihak dalam perjanjian kerja. Menjadi penting kemudian untuk mengetahui bagaimana sebenarnya konstruksi hukum kesetaraan para pihak dalam perjanjian kerja. Lebih lanjut, hal yang patut untuk ditelaah 
adalah ketika pertimbangan hukum Mahkamah Konstitusi kemudian mendudukkan asas kebebasan berkontrak sebagai salah satu syarat sahnya perjanjian, padahal bila merujuk pada Pasal 1320 KUHPerdata syarat sahnya suatu perjanjian adalah: (a) sepakat mereka yang mengikatkan dirinya; (b) kecakapan untuk membuat suatu perikatan; (c) suatu hal tertentu; dan (d) suatu sebab yang halal.

Pengaturan tersebut jelas menunjukkan bahwa asas kebebasan bukanlah syarat sah perjanjian sebagaimana disebutkan dalam pertimbangan hukum Mahkamah Konstitusi. Menjadi menarik untuk menganalisis bagaimana konsekuensi yuridis pertimbangan hukum Mahkamah Konstitusi yang bertentangan dengan syarat sah perjanjian dalam KUHPerdata. Apakah suatu pertimbangan hukum dalam putusan Mahkamah Konstitusi memiliki kekuatan hukum mengikat dan bagaimana implikasinya terhadap norma dalam KUHPerdata yang secara positif masih berlaku?

\section{B. Rumusan Masalah}

Berdasarkan latar belakang di atas, maka permasalahan yang diangkat dalam penelitian ini adalah

1. ApakahtepatsikapmajelisHakimKonstitusi yang meyakini adanya prinsip kesetaraan para pihak dalam perjanjian kerja menurut Undang-Undang Ketenagakerjaan?

2. Bagaimana konsekuensi yuridis pertimbangan hukum Mahkamah Konstitusi yang menyatakan Pasal 153 ayat (1) huruf f Undang-Undang Ketenagakerjaan bertentangan dengan syarat sah perjanjian dalam KUHPerdata?

\section{Tujuan dan Kegunaan}

Tujuan umum dari penelitian ini bertujuan untuk mengetahui, memahami, menelaah, dan menganalisis implikasi Putusan Nomor 13/ PUU-XV/2017 perihal pengujian UndangUndang Ketenagakerjaan terhadap UUD NRI 1945, khususnya Pasal 153 ayat (1) huruf f yang mengatur larangan pernikahan antarkaryawan sekantor. Secara khusus, penelitian ini bertujuan untuk: (a) mengetahui, memahami, menelaah, dan menganalisis konstruksi hukum kesetaraan para pihak dalam perjanjian kerja; dan (b) mengetahui, memahami, menelaah, dan menganalisis konsekuensi yuridis pertimbangan hukum Mahkamah Konstitusi yang bertentangan dengan syarat sah perjanjian dalam KUHPerdata.

Kegunaan dari penelitian ini adalah:

1. Bagi pengembangan ilmu pengetahuan, penelitian ini diharapkan dapat memberikan manfaat bagi pengembangan ilmu hukum, khususnya dalam bidang hukum ketenagakerjaan, terutama mengenaihal-hal yang berkaitan dengan konstruksi hukum kesetaraan para pihak dalam perjanjian kerja. Adapun dalam konteks hukum tata negara, penelitian memberikan manfaat terkait kajian kekuasaan kehakiman, khususnya dinamika praktik kewenangan Mahkamah Konstitusi dalam melaksanakan kewenangan pengujian undang-undang. Selain itu, temuan dalam penulisan ini, diharapkan dapat berguna sebagai dasar perumusan konstruksi hukum yang tepat untuk menjamin kesetaraan para pihak dan pemenuhan hak yang diperjanjikan dalam perjanjian kerja.

2. Bagi praktik ketenagakerjaan dan ketatanegaraan, penelitian ini diharapkan 
memberikan manfaat untuk dalam merumuskan pengaturan yang memberikan jaminan perlindungan dan pemenuhan hak pekerja yang dituangkan dalam perjanjian kerja.

\section{Tinjauan Pustaka}

\section{Konstruksi Hukum Perjanjian dalam Hubungan Kerja}

Menurut Subekti (1983: 1), suatu perjanjian adalah suatu peristiwa di mana seorang berjanji pada seorang lain atau di mana dua orang itu saling berjanji untuk melaksanakan sesuatu hal, yang mana pada peristiwa tersebut timbul suatu hubungan antara dua orang tersebut yang disebut dengan perikatan. Perikatan sebagaimana dimaksud pada Pasal 1233 KUHPerdata, bahwa "tiap-tiap perikatan dilahirkan, baik karena perjanjian baik karena undang-undang." Hal tersebut dipertegas kembali dalam Pasal 1313 KUHPerdata yang menyebutkan bahwa, "suatu perjanjian adalah suatu perbuatan di mana satu orang atau lebih mengikatkan diri terhadap satu orang atau lebih.”

Merujuk pada rumusan dalam Pasal 1313 KUHPerdata, maka perjanjian mengakibatkan seseorang mengikatkan dirinya pada orang lain. Hal ini berarti, dari suatu perjanjian lahirlah kewajiban atau prestasi dari satu atau lebih pihak kepada pihak lainnya yang berhak atas prestasi tersebut. Konsekuensi hukum yang timbul dari rumusan tersebut di atas ialah bahwa dalam suatu perjanjian ada dua pihak atau lebih yang mana masing-masing pihak tersebut wajib untuk berprestasi dan pihak lainnya berhak atas prestasi tersebut (Muljadi \& Widjaja, 2008: 92).

Beberapa asas yang berkaitan dengan perjanjian, antara lain asas kebebasan berkontrak, asas konsensualisme, dan asas pacta sunt servanda. Asas kebebasan berkontrak sebagaimana dimaksud diatur dalam Pasal 1338 ayat (1) KUHPerdata yang menyatakan bahwa semua perjanjian yang dibuat secara sah berlaku sebagai undang-undang bagi mereka yang membuatnya. Sah sebagaimana dimaksud mengacu pada syarat sahnya perjanjian yang termuat dalam Pasal 1320 KUHPerdata. Penerapan asas kebebasan berkontrak ini memiliki batasan dalam pelaksanaannya. Kebebasan seseorang dalam membuat perjanjian tersebut hanya sejauh perjanjian yang dibuatnya itu tidak bertentangan dengan kesusilaan, ketertiban umum, dan undangundang sebagaimana disebutkan dalam Pasal 1337 KUHPerdata (Meliala, 1983: 19).

Asas konsensualisme sebagaimana yang diatur dalam Pasal 1320 KUHPerdata. Pengaturan mengenai asas konsensualisme juga terdapat dalam Pasal 1329 KUHPerdata yang memuat bahwasanya setiap perjanjian itu adalah sah, dalam arti mengikat apabila sudah tercapai kata sepakat mengenai hal-hal pokok dari apa yang diperjanjikan (Meliala, 1983: 21). Suatu perjanjian dinyatakan lahir sejak tercapainya kesepakatan oleh para pihak yang melahirkan hak dan kewajiban bagi para pihak dalam perjanjian tersebut.

\section{Diatur dalam Pasal 1338 ayat}

KUHPerdata bahwa semua perjanjian yang dibuat secara sah berlaku sebagai undang-undang bagi mereka yang membuatnya. Sebagai perikatan yang dibuat dengan sengaja atas kehendak para pihak secara sukarela, maka segala sesuatu yang telah disepakati para pihak harus dilaksanakan oleh para pihak sebagaimana yang dikehendaki oleh mereka. Dalam hal salah satu pihak dalam perjanjian tidak melaksanakannya, maka pihak lain dalam perjanjian berhak untuk memaksakan 
pelaksanaannya melalui mekanisme dan jalur hukum yang berlaku (Muljadi \& Widjaja, 2008: 59).

Guna memiliki kekuatan hukum yang dapat dipatuhi oleh para pihak, maka perjanjian harus bersifat legally binding, yaitu sesuai dengan syarat-syarat yang berdasar pada undang-undang yang berlaku (Irsan \& Armansyah, 2016: 64). Menurut Pasal 1320 KUHPerdata, syarat sahnya suatu perjanjian adalah sebagai berikut: (a) sepakat mereka yang mengikatkan dirinya; (b) kecakapan untuk membuat suatu perikatan; (c) suatu hal tertentu; dan (d) suatu sebab yang halal.

Syarat sahnya suatu perjanjian sebagaimana yang disebutkan pertama adalah adanya sepakat mereka yang mengikatkan dirinya. Dua syarat pertama yang terdiri dari kesepakatan para pihak dan kecakapan membuat perjanjian adalah syaratsyarat subjektif, sedangkan dua syarat terakhir merupakan syarat-syarat objektif. Perbedaan jenis syarat perjanjian tersebut memiliki konsekuensi hukum yang berbeda jika tidak terpenuhi. Dalam hal tidak terpenuhinya syarat subjektif suatu perjanjian, maka konsekuensi hukumnya adalah dapat dibatalkan. Dalam hal syarat objektifnya yang tidak terpenuhi, maka konsekuensi hukumnya adalah batal demi hukum.

Lebih lanjut, spesifik terkait perjanjian kerja yang dikembangkan sebagai salah satu varian dari perjanjian, saat ini telah memiliki pengaturan yang bersifat sui generis pada Undang-Undang Nomor 13 Tahun 2003 tentang Ketenagakerjaan, yang mana dalam Pasal 1 angka 14 Undang-Undang a quo disebutkan bahwa perjanjian kerja adalah perjanjian antara pekerja/buruh dengan pengusaha atau pemberi kerja yang memuat syarat-syarat kerja, hak, dan kewajiban para pihak. Secara sederhana Pasal a quo memberikan unsur dari perjanjian kerja, yaitu: (a) perjanjian kerja adalah perjanjian; (b) pihak dalam perjanjian adalah pekerja/buruh dengan pengusaha atau pemberi kerja; (c) perjanjian memuat syarat-syarat kerja, hak, dan kewajiban para pihak. Hal ini menjadi ciri khas yang membedakan perjanjian secara umum dengan perjanjian kerja yang lebih khusus.

Secara konseptual, perjanjian kerja memiliki unsur sebagai berikut (Wijayanti, 2009: 36): (a) adanya pekerjaan (arbeid); (b) di bawah perintah (gezagsverhouding); (c) adanya upah tertentu (loan); dan dalam waktu (tijd) yang ditentukan. Unsur Pertama, pekerjaan (arbeid) sebagai unsur pertama dari suatu perjanjian kerja merupakan unsur pokok yang harus jelas jenis pekerjaannya dan bukan merupakan jenis pekerjaan yang bertentangan dengan peraturan perundang-undangan, kesusilaan, dan ketertiban umum. Pekerjaan sebagaimana dimaksud diberikan dan ditentukan oleh pemberi kerja (pengusaha) pada pekerja. Pekerjaan yang diperjanjikan dan dikerjakan sendiri oleh pekerja tersebut harus berpedoman pada perjanjian kerja (Prinst, 1994: 67).

Unsur Kedua, unsur kedua dalam suatu perjanjian kerja adalah perintah (gezagsverhouding). Perintah sebagaimana dimaksudkan merupakan perintah dari pemberi kerja atau pengusaha pada pekerja. Perintah tersebut merupakan perintah yang tentunya berkaitan dengan pekerjaan yang dilaksanakan oleh pekerja. Unsur perintah sebagaimana dimaksud menimbulkan adanya perintah orang lain dan memegang peranan pokok. Sebab tanpa adanya unsur perintah, hal itu bukanlah perjanjian kerja (Djumialdji, 2008: 7).

Bentuk dari perintah tersebut dapat secara tertulis sebagaimana termuat dalam perjanjian 
kerja, peraturan perusahaan atau perjanjian kerja bersama. Pekerja diwajibkan untuk mentaati seluruh perjanjian kerja yang ada dan berlaku di dalam perusahaan tempatnya bekerja (Harianto, 2016: 211). Pekerja adalah pihak yang menerima perintah dari pengusaha untuk melaksanakan suatu pekerjaan tertentu. Berdasarkan perintah tersebut terlihat adanya hubungan yang bersifat subordinasi/vertikal antara pemberi kerja dan pekerja.

Unsur Ketiga, upah (loan) sebagai unsur ketiga merupakan hak dari pekerja yang telah melaksanakan pekerjaan sebagaimana yang diberikan oleh pemberi kerja atau pengusaha. Pengaturan upah pada Undang-Undang Ketenagakerjaan menyebutkan bahwasanya pemberi kerja atau pengusaha wajib untuk membayarkan upah pada pekerja dan merupakan kewajiban utama dari pemberi kerja atau pengusaha pada pekerja. Upah dalam hukum perjanjian juga dapat dikatakan sebagai bentuk kontra prestasi dari pemberi kerja atau pengusaha atas prestasi pekerja berupa melaksanakan pekerjaan.

Unsur Keempat, waktu (tijd) yang ditentukan sebagai unsur tambahan dalam suatu perjanjian kerja merupakan waktu yang disepakati oleh pemberi kerja atau pengusaha dengan pekerja dalam melaksanakan suatu pekerjaan. Waktu sebagaimana telah disebutkan di atas dibagi menjadi dua, yaitu waktu tertentu dan tidak tertentu, bergantung pada jenis pekerjaannya dan usia pensiun pekerja menurut undang-undang. Berdasarkan perbedaan jangka waktu perjanjian kerja, maka perjanjian kerja dibedakan menjadi dua, yaitu perjanjian kerja waktu tertentu dan perjanjian kerja waktu tidak tertentu. Perjanjian kerja waktu tertentu adalah perjanjian kerja antara pekerja dan pengusaha yang hanya dibuat untuk pekerjaan tertentu yang menurut jenis dan sifat atau kegiatan pekerjaannya akan selesai dalam waktu tertentu (Khakim, 2009: 60).

Jenis perjanjian kerja waktu tertentu adalah untuk jenis pekerjaan yang sifat pekerjaannya selesai dalam waktu tertentu. Menurut UndangUndang Ketenagakerjaan, perjanjian kerja waktu tertentu memiliki jangka waktu dua tahun dengan perpanjangan satu kali selama satu tahun dan pembaruan perjanjian satu kali selama maksimal dua tahun, dengan memenuhi prosedur perpanjangan dan pembaruan sebagaimana yang diatur dalam Undang-Undang Ketenagakerjaan.

Perjanjian kerja waktu tidak tertentu merupakan perjanjian antara pekerja dan pengusaha yang jangka waktunya tidak ditentukan, baik dalam perjanjian, undangundang, maupun kebiasaan, atau terjadi secara hukum karena pelanggaran pengusaha terhadap ketentuan perundang-undangan yang berlaku. Perjanjian sebagaimana dimaksud merupakan jenis perjanjian kerja yang jangka waktunya dibatasi pada usia pensiun dan untuk jenis pekerjaan yang bukan pekerjaan selesai dalam waktu tertentu, melainkan jenis pekerjaan yang berlanjut. Terdapat ketentuan dalam UndangUndang Ketenagakerjaan, manakala mekanisme perpanjangan perjanjian kerja waktu tertentu tidak sesuai sebagaimana yang diatur dalam Undang-Undang Ketenagakerjaan, maka demi hukum perjanjian kerja waktu tertentu tersebut menjadi perjanjian kerja waktu tidak tertentu, yang berarti status dari pekerja beralih menjadi pekerja tetap (Sembiring, 2016: 6).

Diadakannya perjanjian kerja, maka terjalin hubungan kerja antara pemberi kerja dengan penerima kerja (pekerja) yang bersangkutan. Oleh karena itu, selanjutnya akan berlaku ketentuan 
tentang Hukum Ketenagakerjaan antara lain mengenai syarat-syarat kerja, jaminan sosial, kesehatan, dan keselamatan kerja, penyelesaian perselisihan dan pemutusan hubungan kerja (Uwiyono et al., 2014: 54). Pada dasarnya, hubungan kerja merupakan hubungan antara pemberi kerja dengan pekerja yang terjadi setelah diadakannya perjanjian oleh pemberi kerja dengan pekerja tersebut yang memuat pernyataan kesanggupan dari pekerja untuk melaksanakan pekerjaan dan kesanggupan pemberi kerja untuk memberikan hak pekerja ketika pekerja telah melaksanakan kewajibannya berupa pekerjaan tersebut (Sumanto, 2014: 196).

Subjek hukum pendukung hubungan kerja adalah pengusaha sebagai pemberi kerja dan pekerja. Tidak ada hubungan kerja jika subjek hukum pendukungnya bukan pengusaha dan pekerja.Hubungan hukum sebagaimana dimaksud merupakan hubungan hukum yang berlandaskan pada perjanjian kerja yang selanjutnya disebut sebagai hubungan kerja. Hal ini berarti bahwa hanya perjanjian kerja yang dapat melahirkan hubungan kerja (Budiono, 2009: 22).

\section{Konstruksi Putusan Pengujian Undang- Undang pada Mahkamah Konstitusi}

Konstruksi putusan pengujian undangundang pada Mahkamah Konstitusi tidak dapat dilepaskan dari sifat yang melekat pada putusan itu sendiri. Setidaknya bila merujuk pada penormaan dalam Pasal 24C ayat (1) UUD NRI 1945, ditegaskan bahwa kewenangan Mahkamah Konstitusi adalah mengadili pada tingkat pertama dan terakhir yang putusannya bersifat final untuk menguji undang-undang terhadap UndangUndang Dasar. Maksud dari sifat final dalam Pasal a quo adalah putusan Mahkamah Konstitusi langsung memperoleh kekuatan hukum tetap sejak diucapkan dan tidak ada upaya hukum yang dapat ditempuh. Sifat final dalam putusan Mahkamah Konstitusi juga mencakup pula kekuatan hukum mengikat (final and binding) yang langsung memperoleh kekuatan hukum tetap (inkracht van gewijsde) sejak dibacakan (Hardyanto, 2014: 18).

Selain bersifat final dan mengikat (final and binding), sifat lain dari putusan Mahkamah Konstitusi dalam perkara pengujian undangundang adalah bersifat erga omnes, yaitu memiliki kekuatan mengikat secara hukum terhadap seluruh komponen bangsa, sehingga semua pihak harus tunduk dan taat melaksanakan putusan tersebut (Asy'ari et al., 2013: 677). Dengan demikian putusan pengujian undang-undang mengikat tidak hanya bagi para pihak yang berperkara, tetapi juga seluruh warga negara Indonesia. Sifat erga omnes ini yang membedakannya dengan sifat putusan badan peradilan perdata yang hanya berkekuatan mengikat bagi para pihak yang bersengketa (inter partes) (Mertokusumo, 1983: 52).

Sifat erga omnes dalam putusan pengujian undang-undang tidak dapat dilepaskan dari konstruksi undang-undang yang menjadi objek pengujian. Dikarenakan undang-undang adalah salah satu bentuk dari peraturan perundangundangan yang di dalamnya berisi norma hukum yang mengikat secara umum, maka bila kemudian norma undang-undang tersebut dibatalkan oleh Mahkamah Konstitusi, maka mutatis mutandis hilangnya kekuatan hukum mengikat berdampak bagi seluruh warga negara Indonesia.

Lebih lanjut, bila didasarkan pada amar putusan pengujian undang-undang, setidaknya terdapat dua sifat, yaitu bersifat declaratoir dan constitutief. Putusan declaratoir adalah putusan 
hakim yang menyatakan apa yang menjadi hukum, yang mana dalam perkara pengujian undang-undang terhadap Undang-Undang Dasar, putusan mengabulkan bersifat declaratoir karena menyatakan apa yang menjadi hukum dari suatu norma undang-undang, yaitu bertentangan dengan UUD NRI 1945 (Tim Penyusun Hukum Acara Mahkamah Konstitusi, 2010: 55).

Putusan constitutief adalah putusan yang meniadakan suatu keadaan hukum dan atau menciptakan suatu keadaan hukum baru. Dalam konteks pengujian undang-undang, putusan yang mengabulkan berarti menyatakan norma tersebut bertentangan dan tidak memiliki kekuatan hukum mengikat, sehingga menciptakan suatu keadaan hukum baru akibat dibatalkannya norma tersebut.

Merujuk pada uraian mengenai sifat putusan yang didasarkan pada amar putusan, maka dapat dipahami keberadaan amar putusan menjadi aspek yang penting dalam putusan pengujian undang-undang, yang mana dalam Pasal 56 Undang-Undang Nomor 24 Tahun 2003 tentang Mahkamah Konstitusi terdapat beberapa jenis amar putusan, yaitu: (a) ditolak; (b) tidak dapat diterima; dan (c) dikabulkan.

Jenis Pertama, ditolak. Pasal 56 ayat (5) Undang-Undang Mahkamah Konstitusi menyatakan bahwa dalam hal undang-undang tidak bertentangan dengan UUD NRI 1945, baik mengenai pembentukan maupun materinya sebagian atau keseluruhan, amar putusannya menyatakan permohonan ditolak. Amar putusan menolak permohonan biasanya dijatuhkan apabila permohonan tidak beralasan hukum.

Jenis Kedua, tidak dapat diterima (niet ontvankelijk verklaard). Permohonan dinyatakan tidak dapat diterima apabila permohonan tidak memenuhi syarat sebagaimana ditentukan dalam
Pasal 50 dan Pasal 51 Undang-Undang Mahkamah Konstitusi. Ketentuan Pasal 50 telah dihapuskan melalui Putusan Nomor 004/PUU-I/2003 karena dipandang mereduksi kewenangan Mahkamah Konstitusi yang diberikan UUD NRI 1945 dan bertentangan dengan doktrin hirarki norma hukum yang telah diakui dan diterima secara universal. Persyaratan yang harus dipenuhi hanyalah syarat kualifikasi pemohon sebagaimana diatur dalam Pasal 51 Undang-Undang Mahkamah Konstitusi, sehingga apabila syarat sebagaimana dimaksud dalam Pasal 51 tidak terpenuhi maka permohonan dinyatakan tidak dapat diterima (niet ontvankelijk verklaard).

Jenis Ketiga, dikabulkan. Dalam hal Mahkamah Konstitusi berpendapat bahwa permohonan beralasan, amar putusannya menyatakan permohonan dikabulkan, hal tersebut ditindaklanjuti dalam putusan dengan menyatakan materi muatan ayat, pasal, dan/atau bagian dari undang-undang yang bertentangan dengan UUD NRI 1945. Hal ini juga berlaku pada pengujian formal undang-undang, yang mana apabila pembentukan undang-undang tidak memenuhi ketentuan pembentukan undangundang berdasarkan UUD NRI 1945, maka amar putusannya menyatakan permohonan dikabulkan. Putusan Mahkamah Konstitusi yang mengabulkan permohonan wajib dimuat dalam Berita Negara dalam jangka waktu paling lambat 30 hari kerja sejak putusan diucapkan.

Pengaturan dalam Pasal 48 ayat (2) Undang-Undang Mahkamah Konstitusi, memberikan konstruksi sistematika putusan pengujian undang-undang. Unsur dari putusan pengujian undang-undang yang penting dan perlu untuk diperhatikan adalah pertimbangan hukum. Pertimbangan hukum menjadi tempat bagi hakim dalam menuangkan logika hukum sehingga 
sampai pada amar putusan. Terdapat dua hal yang menjadi bagian dari pertimbangan hukum, yaitu (Tim Penyusun Hukum Acara Mahkamah Konstitusi, 2010: 190): (1) ratio decidendi; dan (2) obiter dictum.

Bagian Pertama, ratio decidendi merupakan bagian pertimbangan sebagai dasar atau alasan yang menentukan diambilnya putusan yang dirumuskan dalam amar. Bagian pertimbangan ini tidak dapat dipisahkan dari amar putusan dan mempunyai kekuatan mengikat secara hukum yang dapat dirumuskan sebagai kaidah hukum. Ratio decidendi (jamak: rationes decidendi) adalah sebuah istilah Latin yang sering diterjemahkan secara harfiah sebagai "alasan untuk keputusan itu," "the reason" atau "the rationale for the decision" (Huda, 2011: 84).

Huda dengan merujuk pada pendapat Pudjosewojo (1976: 30) mendefinisikan sebagai faktor-faktor yang sejati (material fact), faktorfaktor yang esensial yang justru mengakibatkan keputusan begitu itu. Sebelumnya Montrose (1957: 124-125) memberikan argumentasi bahwa terminologi ratio decidendi ditujukan secara khusus pada, "[...] the principle of law propounded by the judge as the basis of his decision, a usage which would correspond with judicial usage; and to dispense with a succinct term for the rule of law for which a case is of binding authority."

Montrose hendak menegaskan bahwa ratio decidendi prinsip hukum yang dikemukakan oleh hakim dalam mengambil putusan. Lebih lanjut, Enright (2002: 247) memberikan tiga karakteristik dari ratio decidendi, yaitu: (a) the ratio decidendi is the rule of law; (b) the rule of law determined the case; and (c) the rule of law was deliberated in the case.
Bagian Kedua, obiter dictum. Pada pertimbangan juga terdapat bagian yang tidak mempunyai kaitan langsung dengan masalah hukum yang dihadapi dan karenanya juga tidak berkaitan dengan amar putusan. Hal demikian sering dilakukan karena digunakan sebagai ilustrasi atau analogi dalam menyusun argumen pertimbangan hukum. Bagian ini tidak mempunyai kekuatan mengikat. Obiter dictum (jamak: obiter dicta) adalah penelaahan dan pendapat tambahan yang dibuat oleh hakim, yang seringkali menjelaskan rasionalitas pengadilan pada putusannya dan menawarkan panduan dalam hal terjadi perkara yang sejenis di masa yang akan datang, yang mana secara hukum tidak mengikat.

Terlepas dari sifat dan konstruksi putusan pengujian undang-undang di atas, secara historis terdapat beberapa pembatasan dalam putusan Mahkamah Konstitusi yang berasal dari risalah sidang Panitia Ad Hoc (PAH) dalam pembentukan Mahkamah Konstitusi, yaitu:

1. Putusan Mahkamah Konstitusi tidak dapat memuat isi yang bersifat mengatur. Putusan Mahkamah Konstitusi hanya dapat menyatakan bahwa sebuah undang-undang atau sebagian dari isi undang-undang tersebut bertentangan dengan bagian tertentu dari Undang-Undang Dasar.

2. Putusan Mahkamah Konstitusi tidak dapat membatalkan undang-undang atau sebagian dari isi undangundang, yang oleh Undang-Undang Dasar kewenangannya diatribusikan kepada undang-undang.

3. Putusan Mahkamah Konstitusi tidak dapat melebihi dari apa yang dimintakan oleh para pemohon (ultra petita). Sekalipun Mahkamah Konstitusi melihat bahwa terdapat hal penting dari permohonan tersebut yang tidak dipinta untuk diputuskan, 
maka Mahkamah Konstitusi tidak diperkenankan memutuskannya berdasarkan asumsi Mahkamah Konstitusi sendiri.

4. Putusan Mahkamah Konstitusi tidak dapat menyentuh hal-hal yang berkaitan dengan Mahkamah Konstitusi atau menyangkut lembaga peradilan. Pendapat tersebut didasari kepada asas hukum, yaitu nemo judex in causa sua atau nemo judex idoneus in propria causa, sebagai sebuah asas hukum universal yang menentang hakim memutuskan perkara yang berkaitan dengan dirinya sendiri dan/ atau yang berkaitan dengan lembaga peradilan (Mahfud MD, 2006: 37).

\section{METODE}

Penelitian dilakukan melalui penelitian hukum normatif, dengan mengkaji dan menganalisis peraturan perundang-undangan atau bahan hukum lain yang berkaitan dengan implikasi Putusan Nomor 13/PUU-XV/2017 terhadap kesetaraan pihak dalam perjanjian kerja. Penelitian hukum ini dilakukan melalui pendekatan peraturan perundang-undangan (statutory approach) dan pendekatan konseptual (conceptual approach) (Marzuki, 2007: 93-95). Selain itu, penelitian ini juga menggunakan metode penelitian studi kasus yang secara fokus mengkaji dan menelaah Putusan Nomor 13/PUU-XV/2017.

Pendekatan peraturan perundang-undangan dilakukan dengan mengkaji peraturan perundangundangan yang terkait dengan tema penelitian, sedangkan pendekatan kasus dilakukan dengan pendekatan khusus terhadap Putusan Nomor 13/ PUU-XV/2017. Adapun pendekatan konseptual dengan menggunakan teori dan doktrin yang terkait dengan asas-asas dalam hukum perjanjian, khususnya bila dikaitkan dengan perjanjian kerja.
Penelitian hukum normatif ini menggunakan jenis data sekunder atau data yang diperoleh melalui bahan kepustakaan, sehingga metode pengumpulan data dilaksanakan dengan mencari pustaka yang relevan, baik melalui perpustakaan maupun pusat data jurnal daring.

Pengumpulan data sekunder yang digunakan dalam penelitian ini difokuskan pada: (a) bahan hukum primer, berupa peraturan perundang-undangan yang terkait dengan tema penelitian; dan (b) bahan hukum sekunder, berupa buku referensi dan jurnal yang terkait dengan tema penelitian dan menguraikan lebih lanjut bahan hukum primer dalam konteks teoretis dan implementasi yang relevan. Data yang terkait implikasi Putusan Nomor 13/PUU-XV/2017 terhadap kesetaraan pihak dalam perjanjian kerja dianalisis secara kualitatif.

\section{HASIL DAN PEMBAHASAN}

\section{A. Konstruksi Hukum Kesetaraan Pihak dalam Perjanjian Kerja dan Jaminan Pemenuhan Hak Pekerja}

Konstruksi hukum kesetaraan para pihak dalam perjanjian kerja tidak dapat dilepaskan dari pengaturan pada Pasal 1313 KUHPerdata yang menyebutkan bahwasanya perjanjian ialah melibatkan di dalamnya dua orang atau lebih yang menimbulkan hak dan kewajiban antar kedua pihak tersebut. Selanjutnya, bila merujuk pada Pasal 1320 KUHPerdata bahwasanya ada unsur kesepakatan dalam suatu perjanjian, yang berarti perjanjian tersebut harus ada kata sepakat antara para pihak yang membuat perjanjian.

Kesepakatan sebagaimana dimaksud merupakan pertemuan dua kehendak yaitu kehendak orang yang satu saling mengisi dengan apa yang dikehendaki pihak lain (Satrio, 1992: 
128). Pada saat pembentukan kata sepakat (toestemming) terdapat unsur penawaran (offer, offerte) dan penerimaan (acceptance, acceptatie). Penawaran sebagaimana dimaksud merupakan pernyataan dari satu pihak mengenai usul suatu ketentuan perjanjian atau usul untuk menutup perjanjian kepada pihak lainnya yang menerima penawaran. Sedangkan penerimaan adalah persetujuan akhir terhadap suatu penawaran. Saat terjadinya penerimaan tersebut merupakan unsur terpenting dalam menentukan lahirnya perjanjian (Khairandy, 2014: 168-169).

Kesepakatan tersebut menunjukkan adanya suatu hubungan horizontal (sejajar) antara para pihak yang melakukan perjanjian, yang mana hubungan tersebut mengindikasikan adanya kesetaraan antara para pihak yang membuat perjanjian. Tanpa adanya suatu unsur kesepakatan, maka tidak akan terpenuhi salah satu unsur subjektif suatu perjanjian, yaitu unsur subjektif tersebut. Tidak terpenuhinya salah satu unsur subjektif suatu perjanjian mengakibatkan dapat dibatalkannya suatu perjanjian tersebut.

Pada suatu perjanjian kerja, para pihak adalah pengusaha dan pekerja. Terkait dengan unsur sepakat dalam suatu perjanjian, maka kesepakatan haruslah bebas. Bebas berarti tidak terdapat cacat kehendak yang meliputi penipuan (dwang), paksaan (dwalling), dan kekhilafan (bedrog). Pada praktik ketenagakerjaan, dalam pembuatan perjanjian kerja, pekerja tidak secara mutlak dapat menentukan kehendaknya yang kemudian dituangkan dalam perjanjian kerja (Wijayanti, 2009: 43).

Berdasarkan hal tersebut, maka kedudukan para pihak dalam suatu perjanjian kerja adalah subordinasi, yaitu ada pihak yang memerintah dan ada pihak yang diperintah. Pihak yang memerintah sebagaimana dimaksud adalah pengusaha, sebagaimana yang telah disebutkan dalam unsur-unsur perjanjian kerja, salah satunya adalah perintah dari pengusaha pada pekerja, maka pihak yang diperintah dalam suatu hubungan kerja berdasarkan perjanjian kerja adalah pekerja. Kedudukan subordinasi yang timbul dari suatu hubungan kerja berdasarkan perjanjian kerja tersebut merupakan suatu ciri khas dari perjanjian kerja yang membedakannya dengan perjanjian lain.

Kedudukan yang tidak setara antara kedua belah pihak yang membuat perjanjian kerja tersebut memerlukan hadirnya peran pemerintah untuk memberikan perlindungan bagi pihak yang dianggap lemah. Kehadiran pemerintah dalam suatu hubungan kerja ialah sebagai bentuk perlindungan bagi pekerja dalam suatu hubungan kerja. Hal ini terkait kedudukan pekerja yang dianggap sebagai pihak yang lemah dalam suatu hubungan kerja dibandingkan dengan pengusaha.

Perjanjian kerja antara pengusaha dan pekerja tersebut menimbulkan adanya hak dan kewajiban antara kedua belah pihak yang membuat dan menyepakatinya. Kehadiran pemerintah dalam suatu hubungan kerja salah satu tujuannya ialah agar dapat dipenuhinya hak dan kewajiban yang dituangkan dalam perjanjian kerja yang harus dilaksanakan oleh pengusaha dan pekerja dalam suatu hubungan kerja. Selain itu, pemerintah dalam hubungan kerja juga berperan dalam menyelesaikan suatu perselisihan hubungan industrial.

Salah satu hak pekerja yang dilindungi dalam Undang-Undang Ketenagakerjaan adalah hak untuk membangun keluarga dalam perkawinan yang sah. Pasal 153 ayat (1) huruf $\mathrm{f}$ disebutkan adanya larangan penjatuhan 
pemutusan hubungan kerja dengan alasan, "pekerja/buruh mempunyai pertalian darah dan/atau ikatan perkawinan dengan pekerja/ buruh lainnya di dalam satu perusahaan, kecuali telah diatur dalam perjanjian kerja, peraturan perusahaan, atau perjanjian kerja bersama."

Peran pemerintah dalam hubungan kerja adalah membuat suatu regulasi yang dapat mengakomodir kepentingan kedua belah pihak dalam perjanjian kerja. Seperti halnya regulasi terkait ketenagakerjaan sebagaimana tersebut di atas. Hanya saja masih ada suatu kelonggaran yang diberikan pada pengusaha sebagai pemberi kerja pada pasal tersebut, yaitu: “[...] kecuali telah diatur dalam perjanjian kerja, peraturan perusahaan, atau perjanjian kerja bersama."

Dikatakan suatu kelonggaran bagi pengusaha atas Pasal tersebut karena mengingat kembali kedudukan antara pengusaha dan pekerja tidak setara dalam suatu perjanjian kerja. Oleh karena itu, dalam kebijakan terkait hal tersebut di atas merupakan adanya suatu "paksaan" terhadap pekerja untuk tidak boleh memiliki hubungan pertalian darah dan/atau perkawinan dalam suatu perusahaan ketika diatur lebih lanjut dalam perjanjian kerja, peraturan perusahaan atau perjanjian kerja bersama.

Pasca Putusan Nomor 13/PUU-XV/2017, sejatinya hak untuk membangun keluarga dalam perkawinanyangsahtelahdijaminpemenuhannya, yang mana sebenarnya hal ini sudah lazim bila hendak menggunakan pendekatan perbandingan hukum. Filipina menyebut pengaturan ini nospouse employment sebagaimana diatur dalam Article 136 pada Presidential Decree Number 442 on Labor Code of the Philippines yang berbunyi sebagai berikut:

Stipulation against marriage. It shall be unlawful for an employer to require as a condition of employment or continuation of employment that a woman employee shall not get married, or to stipulate expressly or tacitly that upon getting married, a woman employee shall be deemed resigned or separated, or to actually dismiss, discharge, discriminate or otherwise prejudice a woman employee merely by reason of her marriage.

Pasal tersebut menegaskan bahwa pekerja wanita di Filipina tidak diperbolehkan mendapatkan suatu bentuk diskriminasi dilakukan pemutusan hubungan kerja padanya oleh pemberi kerja dengan alasan pekerja perempuan tersebut tidak boleh menikah, atau harus mengundurkan diri ketika hendak menikah, atau dilakukan pemutusan hubungan kerja atasnya karena melakukan pernikahan.

Hal serupa di Amerika Serikat dikenal dengan konsep Bona Fide Occupational Qualification, yang disebut sebagai "affirmative defense" yang terdapat dalam Title VII of the Civil Rights Act of 1964, yang berbunyi: "prohibits discrimination in the terms and conditions of employment based on the protected categories or characteristics of race, color, religion, sex, and national origin" atau larangan diskriminasi dalam syarat dan kondisi kerja berdasarkan kategori yang dilindungi atau karakteristik ras, warna kulit, agama, jenis kelamin, dan asal negara. Aturan mengenai no-spouse employment masuk dalam kategori perlindungan tersebut. Lebih lanjut dalam SEC. 2000e-2 [Section 703] Title VII of the Civil Rights Act of 1964 disebutkan sebagai berikut:

It shall be an unlawful employment practice for an employer:

1. to fail or refuse to hire or to discharge any individual, or otherwise to discriminate against any individual with respect to his compensation, 
terms, conditions, or privileges of employment, because of such individual's race, color, religion, sex, or national origin; or

2. to limit, segregate, or classify his employees or applicants for employment in any way which would deprive or tend to deprive any individual of employment opportunities or otherwise adversely affect his status as an employee, because of such individual's race, color, religion, sex, or national origin.

Bahwasanya tidak sah dilakukannya pemutusan hubungan kerja pada pekerja dengan alasan adanya suatu pertalian darah atau terikat dengan pernikahan dengan pekerja lain di satu tempat kerja.

Berkaca pada praktik pada dua negara tersebut, maka telah sewajarnya Indonesia menerapkan hal yang serupa terkait perlindungan pekerja dengan kebijakan no-spouse employment atau Bona Fide Occupational Qualification. Saat ini, pasca Putusan Nomor 13/PUU-XV/2017, sejatinya Mahkamah Konstitusi melalui Putusan a quo memberikan "arahan secara implisit" kepada pembentuk undang-undang untuk lebih melindungi hak pekerja, khususnya terkait kebijakan no-spouse employment. Diperlukan tindak lanjut melalui penormaan yang secara tegas melindungi hak pekerja untuk membangun keluarga dalam perkawinan yang sah.

Terkait dengan pertimbangan hukum Putusan a quo, bahwasanya suatu perjanjian kerja tidak dapat disamakan dengan perjanjian pada umumnya. Suatu perjanjian kerja memiliki ciri khas utama mengenai subordinasi kedudukan para pihak dalam perjanjian kerja tersebut. Subordinasi dapat terlihat dari unsur-unsur yang harus termuat dalam suatu hubungan kerja yang mendasarkannya pada perjanjian kerja yaitu unsur perintah. Keberadaan unsur tersebut secara eksplisit telah memperjelas posisi para pihak dalam perjanjian kerja yang tidak setara. Berangkat dari ketidaksetaraan tersebut, maka hadirlah pemerintah dalam suatu hubungan kerja guna melindungi pekerja sebagai pihak yang dianggap lemah.

\section{B. Pertentangan Pertimbangan Hukum pada Pokok Permohonan Putusan Nomor 13/PUU-XV/2017 dengan Pengaturan dalam KUHPerdata}

Bagian ini membahas mengenai bagaimana konsekuensi yuridis bila pertimbangan hukum pada pokok perkara dalam putusan Mahkamah Konstitusi bertentangan dengan hukum positif, khususnya terkait syarat sah perjanjian dalam KUHPerdata merupakan hal yang relatif rumit. Hal ini dikarenakan Indonesia cenderung tidak dapat disebut sebagai negara yang menerapkan common law sehingga asas stare decisis tidak dapat dinyatakan berlaku secara ketat, namun demikian, Indonesia juga tidak dapat disebutkan sebagai negara yang sepenuhnya menerapkan civil law system, walaupun memang Indonesia memiliki kecenderungan sebagai negara penganut aliran Eropa Kontinental, yang mau tidak mau merupakan dampak politik kolonial.

Sejatinya permasalahan tersebut dapat dianalisis dengan menguraikan beberapa hal berikut:

\section{Kualifikasi Pertimbangan Hukum dalam Putusan Mahkamah Konstitusi}

Hal ini menjadi aspek pertama yang harus dilihat mengenai pertimbangan hukum dalam putusan Mahkamah Konstitusi. Kualifikasi ini tidak dapat dilepaskan dari konstruksi putusan pengujian undang-undang pada Mahkamah 
Konstitusi yang diatur pada Undang-Undang Mahkamah Konstitusi, yang lebih lanjut diatur pada Peraturan Mahkamah Konstitusi Nomor 06/PMK/2005 tentang Pedoman Beracara dalam Perkara Pengujian Undang-Undang. Sebagaimana telah diuraikan sebelumnya putusan pengujian undang-undang harus memuat mengenai pertimbangan terhadap fakta yang terungkap dalam persidangan dan pertimbangan hukum yang menjadi dasar putusan.

Pengaturan pada Pasal 34 Peraturan Mahkamah Konstitusi Nomor 06/PMK/2005 disebutkan bahwa pertimbangan terhadap fakta yang terungkap dalam persidangan meliputi ringkasan: (a) pendirian pemohon terhadap permohonannya dan keterangan tambahan yang disampaikan di persidangan; (b) keterangan Presiden/Pemerintah, DPR, dan/atau DPD; (c) keterangan pihak terkait; dan (d) hasil pemeriksaan alat-alat bukti.

Adapun pertimbangan hukum yang menjadi dasar putusan dirinci pada Pasal 35 Peraturan Mahkamah Konstitusi Nomor 06/PMK/2005, meliputi: (a) maksud dan tujuan permohonan; (b) kewenangan Mahkamah Konstitusi sebagaimana dimaksud Pasal 24 huruf c UUD NRI 1945, Pasal 10 ayat (1) huruf a Undang-Undang Mahkamah Konstitusi; (c) kedudukan hukum (legal standing) sebagaimana dimaksud Pasal 51 ayat (1) dan (2) Undang-Undang Mahkamah Konstitusi; (d) alasan dalam pokok permohonan sebagaimana dimaksud Pasal 51 ayat (3) huruf a dan/atau b Undang-Undang Mahkamah Konstitusi; dan (e) kesimpulan mengenai semua hal yang telah dipertimbangkan.

Mencermati perincian dari kedua jenis pertimbangantersebut, maka dapat ditemuiadanya kesesuaian dengan konsep mengenai substansi pertimbangan hukum, yaitu ratio decidendi dan obiter dicta. Pertimbangan terhadap fakta yang terungkap dalam persidangan dapat dilekati sifat sebagai obiter dicta, sedangkan pertimbangan hukum yang menjadi dasar putusan merupakan ratio decidendi.

Keberadaan ratio decidendi dan obiter dicta dalam putusan seringkali sulit untuk dibedakan (Duxbury, 2008: 68). Terdapat tiga metode yang digunakan untuk mengidentifikasi ratio decidendi dalam sebuah putusan, yaitu (Verma, 2004):

a. Metode Wambaugh. Diperkenalkan oleh Eugene Wambaugh, metode ini jamak disebut inversion test yang didasarkan pada asumsi bahwa ratio decidendi adalah aturan umum, yang mana tanpa keberadaan aturan tersebut, maka suatu perkara akan diputus sebaliknya. Wambaugh memberikan instruksi untuk dapat menemukan ratio decidendi dengan menggunakan eksperimen berikut:

In order to make the test, let him first frame carefully the supposed proposition of law. Let him then insert in the proposition a word reversing its meaning. Let him then inquire whether, if the court had conceived this new proposition to be good and to be the point upon which the case ought to turn, the decision could have been the same. If the answer be affirmative, then, however excellent the original proposition may be, the case is not a precedent for that proposition, but if the answer be negative the case is a precedent for the original proposition and possibly for other propositions also (Wambaugh, 1892: 5-6).

Wambaugh menekankan indikasi ratio decidendi pada original proposition yang menjadi dasar dirumuskannya amar putusan oleh hakim. 
b. Metode Halsbury. Diperkenalkan oleh Lord Halsbury atau Hardinge Stanley Giffard, metode ini menekankan pada kepatuhan pengadilan untuk mengikuti hukum positif dan doktrin dalam memutus suatu perkara dan bukan semata pada tunduk pada preseden. Halsbury menyebutkan ratio decidendi dapat dilacak dengan mencari "the enunciation of the reason or principle upon which the question before the Court has really been determined" (Verma, 2004).

c. Metode Goodhart. Diperkenalkan oleh Arthur Lehman Goodhart, metode ini menekankan pada penggunaan fakta oleh hakim dalam pengambilan putusan. Goodhart menuliskan ada cara untuk menemukan ratio decidendi, yaitu:

1. The principle of a case is not found in the reasons given in the opinion.

2. The principle is not found in the rule of law set forth in the opinion.

3. The principle is not necessarily found by a consideration of all the ascertainable facts of the case and the judge's decision.

4. The principle of the case is found by taking account: (a) of the facts treated by the judge as material, and (b) his decision as based on them.

5. In finding the principle it is also necessary to establish what facts were held to be immaterial by the judge, for the principle may depend as much on exclusion as it does on inclusion (Goodhart, 1930: 182).

Merujuk pada konsepsi Goodhart, maka dapat dijelaskan mengapa doktrin tidak mungkin diberi bobot yang sama dengan preseden yuridis. Hakim yang menganggap dirinya terikat oleh preseden akan sampai pada kesimpulan yang sama seperti yang dicapai dalam kasus sebelumnya, kecuali jika ada beberapa fakta lebih lanjut yang dipersiapkan untuk diperlakukan sebagai materi, atau kecuali fakta yang dianggap material dalam kasus sebelumnya tidak ada (Duxbury, 2008: 91).

Berpijak dari kerangka tersebut, maka pertimbangan hukum pada pokok permohonan dalam putusan Mahkamah Konstitusi dapat dikualifikasikan sebagai ratio decidendi. Spesifik dalam konteks Putusan Nomor 13/PUU$\mathrm{XV} / 2017$, pertimbangan hukum dalam pokok permohonan yang terindikasi bertentangan dengan ketentuan Pasal 1320 KUHPerdata merupakan ratio decidendi.

Hal tersebut dikuatkan bila mencermati putusan a quo, bahwa amar putusan diambil dengan mendasari dua hal, yaitu: (a) Mahkamah Konstitusi menegaskan bahwa perkawinan adalah takdir, sehingga tidak dapat menjadi dasar pembatasan hak asasi manusia; dan (b) Mahkamah Konstitusi menegaskan bahwa dalam konstruksi hukum perjanjian kerja tidak memberikan keseimbangan bagi para pihak dalam perjanjian kerja, sehingga karena sejak awal tidak terdapat keseimbangan, maka asas kebebasan berkontrak telah dicederai, karena menurut Mahkamah Konstitusi asas kebebasan berkontrak merupakan sebagai salah satu syarat sahnya perjanjian.

Mendasarkan pada kedua pertimbangan hukum tersebut, kemudian majelis hakim pada Mahkamah Konstitusi bermufakat untuk mengabulkan permohonan para pemohon untuk seluruhnya dan menyatakan frasa "kecuali telah diatur dalam perjanjian kerja, peraturan perusahaan, atau perjanjian kerja bersama" dalam Pasal 153 ayat (1) huruf f Undang-Undang Ketenagakerjaan bertentangan dengan UUD NRI 1945 dan tidak mempunyai kekuatan hukum mengikat. 


\section{Kekuatan Hukum Mengikat Pertimbangan Hukum dalam Putusan Mahkamah Konstitusi}

Setelah dapat dikualifikasikan bahwa pertimbangan hukum pada pokok permohonan dalam Putusan Nomor 13/PUU-XV/2017 adalah ratio decidendi, maka dapat dijawab kemudian bagaimana kekuatan hukum mengikatnya. Konteks ratio decidendi yang menegaskan bahwa perkawinan adalah takdir, sehingga tidak dapat menjadi dasar pembatasan hak asasi manusia relatif tidak menjadi perdebatan, mengingat memang secara naturalia, perkawinan adalah hak asasi yang melekat pada setiap individu. Bahkan bila hendak ditambahkan, pun kemudian perkawinan hendak dibatasi, maka pengaturan pembatasannya tentu bukan dengan perjanjian kerja.

Hal ini ditegaskan dalam Pasal 28J ayat (2) UUD NRI 1945, bahwa dalam menjalankan hak dan kebebasannya, setiap orang wajib tunduk kepada pembatasan yang ditetapkan dengan undang-undang. Tentu yang dimaksud dengan frasa "undang-undang" dalam rumusan Pasal a quo adalah wet in materiele zin dan/atau wet in formele zin, yang konteks materiilnya tentu adalah materi muatan undang-undang berupa norma yang bersifat abstrak-umum dan bukan dalam bentuk perjanjian kerja yang berisi hubungan keperdataan.

Ratio decidendi yang menegaskan bahwa dalam konstruksi hukum perjanjian kerja tidak memberikan keseimbangan bagi para pihak dalam perjanjian kerja, sehingga karena sejak awal tidak terdapat keseimbangan, maka asas kebebasan berkontrak telah dicederai, karena menurut Mahkamah Konstitusi asas kebebasan berkontrak merupakan sebagai salah satu syarat sahnya perjanjian, perlu untuk diberikan catatan lebih lanjut.

Catatan Pertama, perjanjian kerja memang tidak mampu menghadirkan keseimbangan di antara para pihak. Betul memang perjanjian kerja dapat dipastikan tidak akan pernah mampu memberikan keseimbangan di antara para pihak dalam perjanjian. Hal ini dikarenakan secara naturalia kedudukan pencari kerja selalu dapat dipastikan lebih rendah daripada pemberi kerja. Hal ini sejalan dengan pendapat Santoso \& Puru, yang mengacu pada pendapat Otto KahnFreund, bahwa dalam perjanjian kerja terdapat ciri penundukan diri (submission), subordinasi (subordination), dan ketidaksamaan daya tawar (inequality of bargaining power) (Santoso \& Puru, 2012: 207; Davies \& Freedland, 1983: 18). Dengan demikian, hal tersebut semakin tegas menunjukkan bahwa perjanjian kerja memang tidak akan pernah mampu menghadirkan di antara para pihak dalam perjanjian kerja.

Catatan Kedua, ketidakseimbangan dalam perjanjian kerja bukanlah merupakan bentuk pencederaan asas kebebasan berkontrak, melainkan memang merupakan keterbatasan asas kebebasan berkontrak dalam hukum perjanjian. Asas kebebasan berkontrak disimpulkan dari Pasal 1338 ayat (1) KUHPerdata bahwa: "semua perjanjian yang dibuat secara sah berlaku sebagai undang-undang bagi mereka yang membuatnya [...]".

Menurut Badrulzaman et al. (2001: 84), frasa "semua" dalam Pasal a quo mengandung arti meliputi seluruh perjanjian, baik yang namanya disebut maupun yang tidak disebut oleh undangundang, yang mana asas kebebasan berkontrak (contractvrijheid) berhubungan dengan isi perjanjian, yaitu kebebasan menentukan "apa" 
dan dengan "siapa" perjanjian itu diadakan. Istilah "semua" pada Pasal a quo mengandung asas kebebasan berkontrak (freedom of contract; partij autonomie; contract der vrijheid beginsel) yang memberikan kebebasan kepada para pihak untuk membuat kontrak (perjanjian) apapun isinya dan apapun bentuknya (Rokhim, 2016: 2).

Menurut Sjahdeini (1993: 47), asas kebebasan berkontrak menurut hukum perjanjian Indonesia meliputi ruang lingkup sebagai berikut: (a) kebebasan untuk membuat atau tidak membuat perjanjian; (b) kebebasan untuk memilih pihak dengan siapa ia ingin membuat perjanjian; (c) kebebasan untuk menentukan atau memilih causa dari perjanjian yang akan dibuatnya; (d) kebebasan untuk menentukan objek perjanjian; (e) kebebasan untuk menentukan bentuk suatu perjanjian; dan (f) kebebasan untuk menerima atau menyimpangi ketentuan undang-undang yang bersifat opsional (aanvullend, optional).

Merujuk pada pendapat Budiyono (2012: 10), asas kebebasan berkontrak sejatinya mensyaratkan adanya kesetaraan dari para pihak yang membuat kontrak, walaupun sejatinya kesetaraan yang sebenar-benarnya sesungguhnya tidak ada. Lebih lanjut, Pitlo menegaskan bahwa kebebasan berkontrak pada dasarnya adalah sebuah fiksi, sehingga persangkaan (presumption) yang dianggap ada adalah kesetaraan minimal, artinya pada batas minimal seseorang masih memiliki kesempatan untuk mempergunakan kehendak bebas (free will) untuk masuk atau tidak masuk dalam perjanjian (Budiyono, 2012: 10; Pitlo, 1973).

Titik kritis pada konstruksi hukum dari asas kebebasan berkontrak sejatinya ada pada alam ide yang tidak koheren dengan realitas kehidupan, yaitu ketiadaan ekualitas dan kebebasan yang absolut, sehingga dalam kondisi yang demikian, kebebasan berkontrak sejatinya dibangun di atas fiksi kebebasan dan ekualitas masyarakat (Budiyono, 2012: 11). Dengan penjelasan di atas, maka dapat disimpulkan bahwa ketidakseimbangan dalam perjanjian kerja bukanlah merupakan bentuk pencederaan asas kebebasan berkontrak. Hal ini dikarenakan adanya keterbatasan asas kebebasan berkontrak dalam hukum perjanjian, khususnya dalam konteks perjanjian kerja, asas kebebasan berkontrak hanya berada sampai pada titik kebebasan untuk membuat atau tidak membuat perjanjian dan kebebasan untuk memilih pihak dengan siapa ia ingin membuat perjanjian.

Catatan Ketiga, asas kebebasan berkontrak bukanlah syarat sahnya perjanjian. Catatan ini menjadi catatan yang paling serius mengingat Mahkamah Konstitusi dapat dikatakan salah mengacu ketentuan dalam hukum positif, yaitu Pasal 1320 KUHPerdata, yang menyebutkan dengan jelas supaya terjadi persetujuan yang sah, perlu dipenuhi empat syarat, yaitu: (a) kesepakatan mereka yang mengikatkan dirinya; (b) kecakapan untuk membuat suatu perikatan; (c) suatu pokok persoalan tertentu; dan (d) suatu sebab yang tidak terlarang. Keempat syarat tersebut bersifat kumulatif, yang mana ketiadaan salah satu dari syarat sah tersebut dapat mengakibatkan perjanjian batal demi hukum atau dapat dibatalkan, tergantung syarat mana yang tidak dipenuhi apakah syarat subjektif atau objektif.

Menjadi pertanyaan kemudian, bila pertimbangan hukum pada pokok perkara ini adalah ratio decidendi, yang notabene mempunyai kekuatan hukum mengikat karena menjadi dasar dalam pengambilan putusan, maka bagaimana bila terdapat kesalahan dalam merumuskan ratio 
decidendi? Secara normatif, Putusan Nomor 13/ PUU-XV/2017 tetap memiliki kekuatan hukum mengikat, walaupun untuk ratio decidendi-nya perlu untuk ditelaah lebih lanjut. Setidaknya amar putusan a quo tetap relevan karena adanya ratio decidendi yang menegaskan bahwa perkawinan adalah takdir, sehingga tidak dapat menjadi dasar pembatasan hak asasi manusia. Ratio decidendi yang menyatakan bahwa asas kebebasan berkontrak telah dicederai dengan adanya ketidakseimbangan dalam perjanjian kerja, sedangkan asas kebebasan berkontrak merupakan sebagai salah satu syarat sahnya perjanjian, perlu untuk dikaji lebih mendalam.

Belum ada kajian spesifik memang yang meneliti bagaimana bila ratio decidendi bertentangan dengan hukum positif yang notabene tidak sedang diuji oleh Mahkamah Konstitusi. Mendasarkan pada asas presumptio iustae causa atau asas praduga keabsahan, maka norma-norma dalam KUHPerdata, sepanjang terkait syarat sah perjanjian, secara hukum masih mempunyai kekuatan hukum mengikat sepanjang tidak dibatalkan atau digantikan dengan norma yang baru. Dengan demikian, tidak terdapat satu alasan pun Mahkamah Konstitusi untuk merumuskan ratio decidendi bertentangan dengan hukum positif, sebagaimana tertuang dalam putusan a quo yang menyebutkan asas kebebasan berkontrak sebagai salah satu syarat sah perjanjian. Terlebih memang perkara pada putusan a quo juga tidak sedang mempersoalkan mengenai syarat sah perjanjian dalam Pasal 1320 KUHPerdata sebagai objek perkara yang diujikan.

Menurut konteks doktrinal, sejatinya apa yang terjadi pada ratio decidendi yang bertentangan dengan hukum positif dapat dikualifikasikan sebagai bagian dari legal error, yaitu kesalahan sebagai bagian dari human being dan tidak dapat dihindari, yang jamak ditemui dalam pengambilan putusan hakim (Gray, 2004: 1246). Dalam hal hendak meminjam konsep dalam hukum acara pidana, maka hal ini dapat pula dikualifikasikan sebagai bentuk kekhilafan hakim, yaitu pertimbangan hukum putusan secara nyata bertentangan dengan asas-asas hukum dan norma hukum (Chazawi, 2010: 85). Walaupun memang, harus menjadi catatan bahwa amar putusan tidak bermasalah secara yuridis, karena selain didasarkan pada ratio decidendi yang dapat dikatakan salah, tetapi juga didasarkan pada ratio decidendi yang beralasan menurut hukum. Bagaimanapun, pertimbangan hukum dan amar merupakan nyawa atau jiwa yang sebenarnya dari suatu putusan, bahkan baik buruknya putusan dapat diukur dari pertimbangan hukum putusan dan amar yang ditarik berdasarkan pertimbangan hukumnya tersebut (Chazawi, 2010: 84).

\section{KESIMPULAN}

Berdasarkan analisis di atas dapat disimpulkan sebagai berikut:

1. Pemahaman majelis konstitusi tentang adanya kesetaraan para pihak dalam perjanjian kerja menurut Undang-Undang Ketenagakerjaan merupakan sikap yang tidak tepat. Kesetaraan para pihak dalam suatu perjanjian kerja merupakan suatu fiksi dan tidak terwujud karena dalam suatu perjanjian kerja mengandung unsur perintah yang dapat dilaksanakan oleh pihak pengusaha sebagai pemberi kerja pada pekerja sebagai pelaksana kerja. Pemerintah sebagai salah satu pihak dalam suatu hubungan kerja memiliki peran sebagai pihak yang melindungi pihak yang 
lemah dalam pelaksanaan suatu hubungan kerja berdasarkan perjanjian kerja yang di dalamnya terdapat ketidaksetaraan antara para pihak yang membuatnya, demi terpenuhinya hak dan kewajiban masingmasing pihak dalam hubungan kerja.

2. Konsekuensi yuridis atas pertimbangan hukum Mahkamah Konstitusi yang menyatakan bahwa Pasal 152 ayat (1) huruf f bertentangan dengan syarat sah perjanjian dalam KUHPerdata dapat dianalisis dengan menguraikan beberapa hal berikut:

(a) kualifikasi pertimbangan hukum dalam putusan Mahkamah Konstitusi; dan (b) kekuatan hukum mengikat pertimbangan hukum dalam putusan Mahkamah Konstitusi. Pertimbangan hukum dalam Putusan Nomor 13/PUU-XV/2017 dapat dikualifikasikan sebagai ratio decidendi yang menjadi dasar perumusan amar putusan, yang mana ratio decidendi memiliki kekuatan hukum mengikat. Namun demikian, karena salah satu ratio decidendi dapat dinilai bertentangan dengan hukum positif, yang notabene bukan merupakan pokok perkara pengujian undang-undang, maka ratio decidendi yang mendudukkan asas kebebasan berkontrak sebagai syarat sahnya perjanjian dapat dinilai sebagai bentuk legal error atau bahkan sebagai bentuk kekhilafan hakim. Walaupun demikian, Putusan Nomor 13/ PUU-XV/2017 tetap memiliki kekuatan hukum mengikat, karena setidaknya amar putusan a quo tetap relevan karena adanya ratio decidendi yang menegaskan bahwa perkawinan adalah takdir, sehingga tidak dapat menjadi dasar pembatasan hak asasi manusia.

\section{DAFTAR ACUAN}

Asy'ari, S., et al. (2013, Desember). Model \& implementasi Putusan Mahkamah Konstitusi dalam pengujian undang-undang (Studi putusan tahun 2003-2012). Jurnal Konstitusi, 10(4), 675-708.

Badrulzaman, M.D., et al. (2001). Kompilasi hukum perikatan. Cetakan I. Bandung: Citra Aditya Bakti.

Budiono, A.R. (2009). Hukum perburuhan. Jakarta: Indeks.

Budiyono, T. (2012, Desember). Genealogi kontrak (Studi tentang historisitas asas dalam hukum kontrak). Orasi Ilmiah. Salatiga: Fakultas Hukum Universitas Kristen Satya Wacana.

Chazawi, A. (2010). Lembaga peninjauan kembali (PK) perkara pidana. Jakarta: Sinar Grafika.

Davies, P., \& Freedland, M. (1983). Kahn-Freund's labour \& the law. Edisi ke-3. London: Stevens and Sons.

Djumialdji, F.X. (2008). Perjanjian kerja. Jakarta: Sinar Grafika.

Duxbury, N. (2008). The nature \& authority of precedent. Cambridge: Cambridge University Press.

Enright, C. (2002). Legal technique. Sydney: The Federation Press.

Goodhart, A.L. (1930, December). 'Determining the ratio decidendi of a case.' The Yale Law Journal, 40(2), 161-183.

Gray, C. (2004). 'The line between legal error \& judicial misconduct: Balancing judicial independence \& accountability.' Hofstra Law Review, 32(4), 1245-1280.

Hardyanto. (2014). Judicial review Peraturan 
Pemerintah Pengganti Undang-Undang (Perppu) oleh Mahkamah Konstitusi. Tesis. Yogyakarta: Program Studi Magister Ilmu Hukum Program Pascasarjana Universitas Atma Jaya.

Harianto, A. (2016). Hukum ketenagakerjaan: Makna kesusilaan dalam perjanjian kerja. Yogyakarta: LaksaBang.

Huda, M. (2011, Januari). Kamus hukum: Ratio decidendi. Majalah Konstitusi, 48, 84.

Irsan, K., \& Armansyah. (2016). Hukum tenaga kerja: Suatu pengantar. Jakarta: Erlangga.

Khairandy, R. (2014). Hukum kontrak Indonesia: dalam perspektif perbandingan. Yogyakarta: FH UII Press.

Khakim, A. (2009). Dasar-dasar hukum ketenagakerjaan Indonesia. Bandung: Citra Aditya Bakti.

Mahfud MD., M. (2006). Membangun politik hukum, menegakkan konstitusi. Jakarta: Pusat LPES.

Marzuki, P.M. (2007). Penelitian hukum. Cetakan Ketiga. Jakarta: Kencana Prenada Media Group.

Meliala, A.Q.S. (1983). Pokok-pokok hukum perjanjian beserta perkembangannya. Yogyakarta: Liberty.

Mertokusumo, S. (1983). Sejarah peradilan \& perundang-undangannya sejak tahun 1942 \& apakah kemanfaatannya bagi kita bangsa Indonesia. Yogyakarta: Liberty.

Montrose, J.L. (1957, March). 'Ratio decidendi \& the house of lords.' The Modern Law Review, 20, 124-130.

Muljadi, K., \& Widjaja, G. (2008). Perikatan yang lahir dari perjanjian. Jakarta: Rajawali Pers.
Pitlo, A. (1973). Saragih, D. (Ed.). Suatu pengantar azas-azas hukum perdata. Bandung: Alumni.

Prinst, D. (1994). Hukum ketenagakerjaan Indonesia: Buku pegangan bagi para buruh untuk mempertahankan hak-haknya. Bandung: Citra Aditya.

Pudjosewojo, K. (1976). Pedoman pelajaran tata hukum Indonesia. Jakarta: Aksara Baru.

Rokhim, A. (2016, Agustus). Daya pembatas asas kebebasan berkontrak dalam hukum perjanjian. Jurnal Negara dan Keadilan, 5(9), 77-91.

Santoso, B., \& Puru, R.D. (2012, Desember). Eksistensi asas kebebasan berkontrak dalam perjanjian kerja. Arena Hukum, 6(3), 155-226.

Satrio, J. (1992). Hukum perjanjian. Bandung: Citra Aditya Bakti.

Sembiring, J.J. (2016). Hak \& kewajiban pekerja: Berdasarkan peraturan terbaru. Jakarta: Visi Media.

Siahaan, M. (2006). Hukum acara Mahkamah Konstitusi Republik Indonesia. Jakarta: Sekretariat Jenderal dan Kepaniteraan MK RI.

Sjahdeini, S.R. (1993). Kebebasan berkontrak \& perlindungan hukum yang seimbang bagi para pihak dalam perjanjian kredit bank di Indonesia. Cetakan I. Jakarta: Institut Bankir Indonesia.

Subekti. (1983). Hukum perjanjian. Jakarta: Intermasa

Sumanto. (2014). Hubungan industrial: Memahami \& mengatasi potensi konflik-konflik kepentingan pengusaha-pekerja pada era modal global. Yogyakarta: Center of Academic Publishing Service.

Tim Penyusun Hukum Acara Mahkamah Konstitusi. (2010). Hukum acara Mahkamah Konstitusi. 
Jakarta: Sekretariat Jenderal dan Kepaniteraan MKRI.

Uwiyono, A., et al. (2014). Asas-asas hukum perburuhan. Jakarta: Rajawali Pers.

Verma, S. (2004). Jurisprudence notes - Three tests to determine ratio decidendi. Diakses dari http:// www.desikanoon.co.in/2014/05/jurisprudencenotes-three-tests-to.html.

Wambaugh, E. (1892). The study of cases. Boston: Little, Brown, and Company.

Wijayanti, A. (2009). Hukum ketenagakerjaan pasca reformasi. Jakarta: Sinar Grafika. 